\title{
Non-amiloidojenik Transtiretin Gen Varyantlarının Biyoinformatik Analizi ve His90Asn Varyantının Klinik Önemi
}

\section{Bioinformatic Analysis of Non-Amyloidogenic Transtyhretin Gene Variants and Clinical Importance of His90Asn Variant}

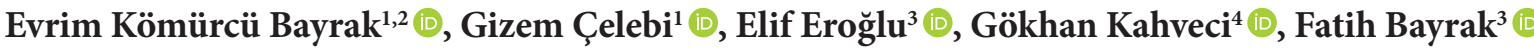

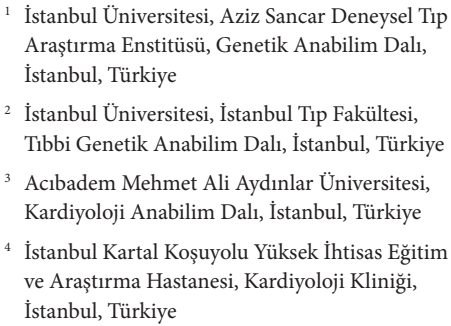
Araştırma Enstitüsü, Genetik Anabilim Dalı, İstanbul, Türkiye

2 İstanbul Üniversitesi, İstanbul Tip Fakültesi, Tibbi Genetik Anabilim Dalı, İstanbul, Türkiye

3 Acıbadem Mehmet Ali Aydınlar Üniversitesi, Kardiyoloji Anabilim Dalı, İstanbul, Türkiye

4 İstanbul Kartal Koşuyolu Yüksek İhtisas Eğitim ve Araştırma Hastanesi, Kardiyoloji Kliniği, İstanbul, Türkiye

ORCID: E.K.B. 0000-0003-1271-1208;

G.C. 0000-0002-7129-3045;

E.E. 0000-0001-6700-9390;

G.K. 0000-0001-8367-6505;

F.B. 0000-0002-1574-1085

Corresponding author/Sorumlu yazar: Evrim Kömürcü Bayrak,

İstanbul Üniversitesi, Aziz Sancar Deneysel Tip

Araştırma Enstitüsü, Genetik Anabilim Dalı,

İstanbul, Türkiye

E-mail: ebayrak@istanbul.edu.tr

Submitted/Bașvuru: 16.09 .2020 Accepted/Kabul: 13.10 .2020

Citation/Atıf: Komurcu Bayrak E, Celebi G, Eroglu E, Kahveci G, Bayrak F. Bioinformatic Analysis of Non-Amyloidogenic Transtyhretin Gene Variants and Clinical Importance of His90Asn Variant. Sağlık Bilimlerinde İleri Araştırmalar Dergisi 2020; 3(3): 102-113.

https://doi.org/10.26650/JARHS2020-795625
ÖZ

Amaç: Transtiretin (TTR) amiloidozu, otozomal dominant kalıtımlı değişken penetransa sahip bir hastalıktır. TTR genindeki patojenik varyantlar, TTR proteininin yanlış katlanmasına yol açarak kardiyomiyositlerde birikime ve kalp yetmezliğine sebep olabilmektedir. Bu çalışmada, biventriküler konsantrik hipertrofisi olan hastada TTR geninde saptanan His90Asn $(\mathrm{H} 90 \mathrm{~N})$ varyantının hastalık patogenezine etkisinin ve non-amiloidojenik varyantlarının biyoinformatik analizlerle klinik önemlerinin belirlenmesi amaçlandı.

Gereç ve Yöntem: İndeks vaka, 18 yll kardiyolojik açıdan takip edildi ve Illumina TruSight Kardiyomiyopati paneli kapsamında 46 genin ekzonik bölgelerindeki varyantlar araştırıldı. TTR geninde H90N varyantı saptanan vakadan klinik olarak amiloidoz şüphesi ile rektal biopsi örneği alındı. Bu varyant, Sanger dizileme yöntemi ile konfirme edildi.

Bulgular: Onbir yıl önce tanı alan ve ICD implante edilen 32 yaşındaki bir erkek vakada TTR geninin ekzon 3'ünde H90N varyantı heterozigot olarak belirlendi. Indeks vaka, kardiyak amiloidoz açısından değerlendirildiğinde, progresif sistolik disfonksiyona sahip olduğu (sol ventrikül ejeksiyon fraksiyonu, 2013'te \%60, 2016'da \%35 ve $2017^{\prime}$ de $\% 20$ ) ve amiloidoz ile uyumlu epikardiyal ve endokardiyal tabakalarda global longutidunal strain (GLS) skoru ve strain rate değerinin azaldığı belirlendi. Rektal biyopsininde kongo kırmızısı boyamasında amiloid birikimi gözlenmedi. Bu varyant, asemptomatik olan babasında da tespit edildi. İlk defa bu çalışmada, TTR genindeki non-amiloidojenik aminoasit değişimine neden olan tüm varyantlar biyoinformatik analizlerle karşılaştırıldı.

Sonuç: Bu çalışmada, H90N varyantının infiltratif miyokard hastalığındaki patojenik etkisi kanıtlanamamıs olsada TTR genindeki H90N varyantı gibi non-amiloidojenik varyantların klinik değerlendirmede dikkate alınması gerektiği ortaya konmuştur.

Anahtar Kelimeler: Kardiyak amiloidoz, transtiretin, His90Asn varyant 1

\section{ABSTRACT}

Objective: Transthyretin (TTR) amyloidosis is an autosomal dominant inherited disease with variable penetration. Cardiac deposition of misfolded TTR protein due to missense pathogenic variants causes heart failure. Our aim was to determine the effect of the TTR gene His90Asn $(\mathrm{H} 90 \mathrm{~N})$ variant on the pathogenesis of disease in a patient with biventricular concentric hypertrophy, and the clinical significance of variants defined as non-amyloidogenic with bioinformatic analysis.

Materials and Methods: The index case was followed cardiologically for 18 years and pathogenic variants were investigated in the exonic regions of 46 genes using the Illumina TruSight Cardiomyopathy panel. Rectal biopsy specimen was taken from a case where the $\mathrm{H} 90 \mathrm{~N}$ variant was detected in the TTR gene, with clinical suspicion of amyloidosis. This variant was confirmed by the Sanger sequencing method.

Results: Heterozygote H90N variant was determined in exon 3 of the TTR gene in index case of a 32-year-old man with severe heart failure who was diagnosed 11 years ago and implanted with an ICD. He had progressive systolic dysfunction (left ventricular ejection fraction, $60 \%$ in $2013,35 \%$ in 2016 , and $20 \%$ in 2017). GLS score and strain rate were reduced in the epicardial and endocardial layers compatible with amyloidosis in the patient. 
In congo red staining of rectal biopsy, amyloid deposition was not observed. This variant was detected also in the patient's father, who did not have clinical symptoms. For the first time in this study, all variants that cause non-amyloidogenic amino acid subtitutions in the TTR gene were compared with bioinformatics analyzes.

Conclusion: In this study, although the pathogenic effect of the H90N variant in infiltrative myocardial disease was not proven, it was revealed that non-amyloidogenic variants such as the $\mathrm{H} 90 \mathrm{~N}$ variant in the TTR gene should be considered in clinical evaluation.

Keywords: Cardiac amyloidosis, transthyretin, His90Asn variant 


\section{GİRIŞ}

İlk kez 150 yll önce keşfedilmiş olan geniş bir protein katlanma hastalık grubu olan amiloidozlara sebep olan amiloid agregatları, $\beta$-kıvrımlı tabaka yapısında sert, çözünmeyen (insolubl), dallanmayan fibriler yapıya sahiptir (1). Şimdiye kadar insanlarda in vivo olarak yaklaşık 36 farklı prekürsör proteinin amiloid agregatları oluşturarak amiloidoza sebep olduğu belirlenmiștir (2). Bu proteinlerden atriyal natriüretik faktör amiloidozu (AANF) kalpte atriyumlara lokalizedir, sistemik olarak ise çoğunlukla böbrek, sinir sistemi, gastrointestinal sistem, dalak ve yumuşak dokular ile birlikte kalpte de amiloid fibrilleri olarak biriken fibrinojen alfa zincir (AFib), apolipoprotein AIV (AApoAIV), apolipoprotein AII (AApoAII), serum amiloid A (AA), immunoglobin ağır zinciri $(\mathrm{AH})$, immunglobin hafif zinciri $(\mathrm{AL})$ ve transtiretin (ATTR) prekürsörleri, kalitsal veya edinsel tipte amiloidozlara sebep olmaktadır (3). Kardiyak amiloidozlar, sonuç olarak oldukça heterojen bir etiyopatogeneze ve kliniğe sahiptir ve çoğunlukla kardiyoloji, nefroloji, nöroloji, hematoloji, radyoloji, genetik ve patolojiyi ilgilendiren multidisipliner yaklaşımlar ile tanının konulabildiği hastalık grubudur.

Transtiretin (TTR) ilişkili amiloidozlar (ATTR), mutant formdaki transtiretin proteini sebebiyle oluşan ailesel ATTRv (amiloid TTR varyantı) ile doğal-tip transtiretin proteini sebebiyle oluşan edinsel veya senil ATTRdt olarak gruplandırılmaktadır (3). ATTRdt, çoğunlukla sadece kalbi etkilerken bazen yumuşak doku tutulumu ile bilateral karpal tünel sendromu, biseps tendon rüptürü ve spinal stenoza da sebep olmaktadır. ATTRv'in ise kardiyak tutulumu yanı sıra sıklıkla kalıtsal sensör ve motor sinir küçük lif polinöropatisi meydana gelir. TTR ilişkili kardiyak amiloidozun klinik seyri, transtiretin fibrilinin doğal veya mutant formda olmasına, hastalığın başlangıç yaşına ve spesifik patojenik varyantlara göre değişmektedir (4).

TTR (prealbümin olarak da adlandırılan) proteini, karaciğer, koroid pleksus ve retinal pigment epitellerinde sentezlenir, 147 aminositlik primer polipeptidden ilk 20 aminositlik sinyal peptid ç1kartılır ve kalan 127 aminoasitten oluşan 14 kDa’luk monomerin iki boyutlu yapısında, bir alfa sarmal
(EF sarmalı) ve 8 beta iplik bulunur (5) (Şekil 1). Plazmada dördüncül formdaki homo-tetramer yapıda, birincil olarak retinolün (Vitamin A) minor olarak tiroksinin (T4) taşınmasından sorumludur. Yaşlanma veya TTR gen varyantları sebebiyle, TTR proteininin tetramer yapısının monomerlere ayrılarak tekrar yanlış katlanmalarla oligomer veya fibril yapılarının oluşmasına bağlı olarak, dokularda amiloid fibril birikimi sonucu organ disfonksiyonu meydana gelmektedir (5). TTR genindeki patojenik varyantlar nedeniyle oluşan amiloidozlar (ATTRv), ailesel amiloid polinöropati (FAP) veya ailesel amiloid kardiyomiyopati (FAC) veya her ikisine birden neden olabilmektedir (6). Günümüzde insan genom mutasyon veri bankasinda (HGMD), TTR geninde 198 adet varyant listelenmektedir ve bunların 191 tanesi aminoasit değişimine neden olan tek nükleotid varyantlarıdır (SNV). Bunlar arasında, amiloid fibrilleri olușturmayıp ancak in vivo fonksiyonel anormalliklere neden olabilen (7) ve non-amiloidojenik olarak gruplandırılan varyantlar da mevcuttur (5). Bu varyantların, farklı popülasyonlarda allel frekansları değişkendir ve özellikle amiloidojenik varyantlar ile birlikte birleşik heterozigositeye sahip olup klinik tabloya ve semptomların şiddetine etki etmektedir (7). Şekil 1'de gösterildiği gibi 127 aminoasitlik matür polipeptid dizisinde 109 . pozisyondaki Alanin, amiloidojenik varyant olarak Serin’e (A109S) değişerek geç başlangıçli, sensör-motor polinöropatisine neden olurken (8), non-amiloidojenik varyantlar olarak Treonin (A109T) veya

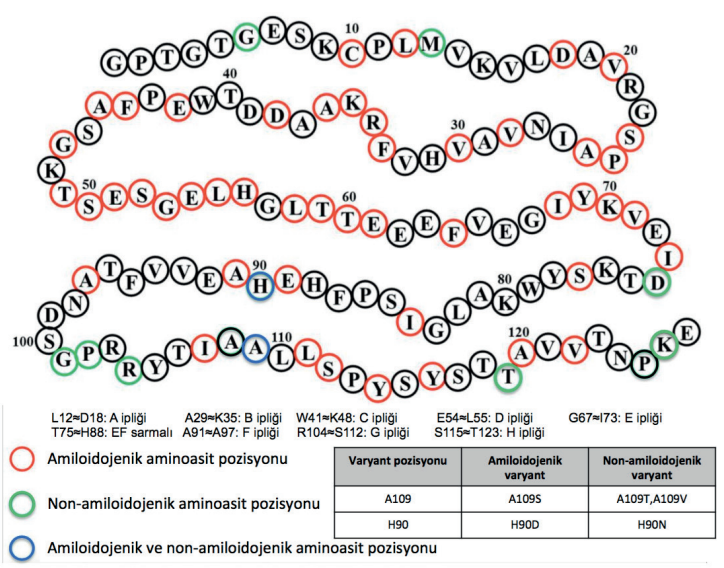

Şekil 1. TTR polipeptidinde amiloidozlar ile ilişkilendirilmiş varyantlar ve pozisyonları $(7,10)$ 
Valin’e (A109V) değiştiğinde dominant kalıtımlı ötiroid hipertiroksinemiye neden olmaktadır (9). Matür polipeptidde 90. Pozisyondaki Histidin, Aspartat’a değiştiğinde (H90D) amiloidojenik varyant olarak geç başlangışlı FAP’a (10) sebep olurken Asparajin’e değiştiğinde (H90N) non-amiloidojenik varyant olarak tanımlanmaktadır $(7,10)$.

Bu çalışmada, kardiyoloji tarafından 18 yıl takip edilmiş ileri biventriküler konsantrik hipertrofili erkek hastada TTR geninde saptanan H90N varyantının hastalık patogenezine etkisinin ve diğer muhtemel non-amiloidojenik varyantların biyoinformatik analizlerle klinik önemlerinin belirlenmesi amaçlandı.

\section{GEREÇ VE YÖNTEMLER}

\section{Vaka Seçimi ve Genetik Analizi}

Bu çalışma kapsamında yapılan genetik araştırma, İstanbul Tip Fakültesi Etik Kurul onayı ile gerçekleştirildi ve katılımcılardan çalışma hakkında bilgilendirme sonrasında onam alındı. İndeks vakanın kardiyolojik değerlendirmeler ve takibi, 16 yaşından 34 yaşında eksitus oluncaya kadar devam etti. Kardiyolojik değerlendirmeler, fizik muayene, elektrokardiyografik ve ekokardiyografik olarak yapıldı.

16 yaşında iken hipertofik kardiyomiyopati (HKM) olarak değerlendirilen indeks vaka 28 yaşındayken kendisinden ve ebeveynlerinden EDTA'l tüplere $10 \mathrm{ml}$ periferik kan alındı. Periferik kandan ayrıştırılan lökositlerinden standart tuzla çöktürme yöntemi ile genomik DNA örnekleri izole edildi. DNA örneklerinin konsantrasyonları nanodrop cihazında ölçüldü. İndeks vakada, kardiyomiyopati ile ilişkili 46 genin ekzonik bölgelerindeki (Illumina TruSight kardiyomiyopati paneli, www.illumina.com/trusight) değişimler, yeni nesil dizileme (YND) platformu ve protokolleri (Illumina MiSeq, U.S.) kullanılarak hizmet alımı şeklinde MiSeq Reporter yazılımı ile araştırıld. Elde edilen vcf (variant call format) dosyaları incelenerek varyantların hastalıkla ilişkilileri değerlendirildi. İndeks vakada, TTR geninde heterozigot olarak belirlenen His90Asn (H90N, His110Asn, $\mathrm{H} 110 \mathrm{~N}$ ) varyantının konfirmasyonu ve aile segregasyon analizi için ebeveynlerinin genotiplemeleri, TTR geni 3. ekzonu daha önce tarif edilen yöntemdeki gibi
(11) Polimeraz Zincir Reaksiyonu (PCR) ve Sanger dizileme ile yapıldı.

\section{Biyoinformatik Analizler}

YND yöntemi ile tanımlanan varyantlar, varyant yazılımı (VariantStudio) ile gen transkriptindeki lokalizasyonları ve amino asit substitüsyonları belirlendi. Varyant minimum allel frekansları (MAF: \%5 altı), dominant kalıtım modeli ve ekzonik pozisyonuna göre filtrelemeler yapılarak varyant listesi incelendi. İndeks vakada, potansiyel olarak hastalık sebebi olarak, TTR genindeki H90N aminoasit değişimine sebep olan c.328C $>$ A varyantı heterozigot olarak belirlendi. Bu varyant ile birlikte TTR genindeki diğer non-amiloidojenik varyantlar, varyant dizilerinin yorumlamasında kullanılan ACMG (American College of Medical Genetics and Genomics) siniflaması (12) ve DANN, MutationTaster, FATHMM, SIFT, PROVEAN, PrimateAl ve GERP araçları kullanılarak elde edilen in siliko analiz sonuçları için VarSome (https://varsome.com/) veritabanında, populasyonlardaki allel sıklıkları (ExAc, erişime açık data) için dbSNP veritabanında (https://www.ncbi. nlm.nih.gov/snp/), ATTRv ile ilişkileri için HGMD (Human Genome Mutation Database; BIOBASE, https://portal.biobase-international.com/cgi-bin/ portal/login.cgi) mutasyon veritabanında araştırıldı.

\section{BULGULAR}

\section{Hasta Hikayesi ve Klinik Değerlendirme}

2001 yılında 16 yaşında iken ilk kardiyolojik değerlendirmelerinde hipertrofik kardiyomiyopati tanısı alarak takip edilen erkek hastaya 5 yıl sonra, tam atriyoventriküler blok sebebi ile DDD kalp pili implantasyonu uygulaması yapıldı. Kardiyoloji takipleri düzenli devam eden hastanın 2013 yılında yapılan ekokardiyografik incelemesinde, ejeksiyon fraksiyonu (EF) \%60, sol ve sağ ventrikül konsantrik hipertrofisi izlendi, interventriküler septum (ivs): $3.3 \mathrm{~cm}$, posterior duvar kalınlığ 1 (pdk): $2.4 \mathrm{~cm}$, mitral yetersizliği 1. seviye olarak değerlendirildi ve lead ekstraksiyonu ile ICD (kardiyak defibrilatör) implantasyonu yapıld1. 2014 yılındaki kontrollerinde, EF \%40 ve biventriküler hipertrofisi olduğu gözlendi. 2016 
yılındaki kontrollerinde ise EF \%35, ivs:3.1 cm, pdk:2.1 $\mathrm{cm}$ olarak belirlendi ve CRT-D upgrade işlemi için yeni sol ventrikül lead implantasyonu yapıldı. Bu işlemden 5 ay sonra "atriyal flutter" bulgusu sebebi ile intrakardiyak kardiyoversiyon, 4 ay sonrasında ventriküler taşikardi için uygun ICD şoklaması ortaya çıktı. 32 yaşında EF'si \%20, biventrikular hipertrofi and sol ventrikül dilatasyonu gözlemlenen hastadan amiloidoz şüphesi ile rektal biopsi $(0.2 \mathrm{~cm}$ çapında 4 doku parçası incelenmiş) uygulaması yapıldı ve histopatolojik olarak kongo kırmızısı boyaması ile incelenen dokularda amiloid birikimi saptanmadi. Ancak ekokardiyografik bulguları, Şekil 2'de gösterildiği gibi kardiyak amiloidoz şüphesini doğrulamaktadır. İndeks vaka 32,5 yaşında iken EKG bulguları Şekil 3'de izlenmektedir. EKG bulguları atriyumdan ve takiben ventrikülden yapılan pil ritmi ile uyumludur. QRS ileri derecede genişlemiştir (320 msn). Aynı zamanda vakada, kısa süreli kooperasyon bozulması ve konuşma bozukluğu gelişmesi sebebi ile nörolojik olarak değerlendirildiğinde kontrastsız kaniyal BT sonucunda, belirgin kanama veya patolojik bulgu saptanmad, karotid ve vertebral arterlerin renkli doppler ultrasonografik incelemesi normal sinırlarda bulundu. Bi-

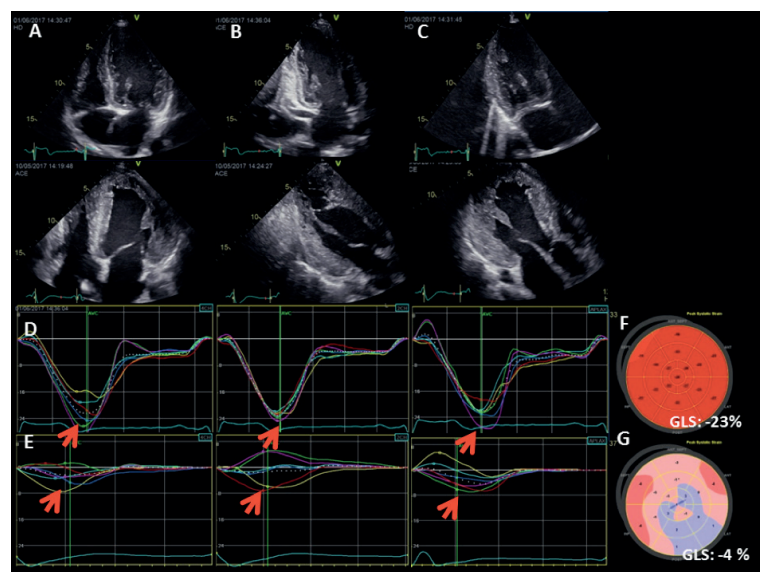

Şekil 2. Sağlıklı kontrol bireyinde Global longutidunal strain (GLS) analizi (üst panel) ve amiloidoz hastasında GLS analiz (alt panel). Strain ölçümleri apikal 4 boşluk (A), 3 boşluk (B), ve 2 boşluk (C) görüntülerinden elde edilmiştir. Pik sistolik strain aortik kapak kapanmasından önceki en negatif değer olarak saptanmıştır (D, E; oklar). GLS, 3 apikal görüntüden elde edilen ortalama pik sistolik strain olarak tanımlanmıştır. 18 segmetli sol ventrikül strain grafikleri izlenmektedir (F, G). Kontrol bireyde normal GLS (-23\%) ve amiloidozlu hastada ciddi azalmış GLS (-4\%) değerleri izlenmiştir

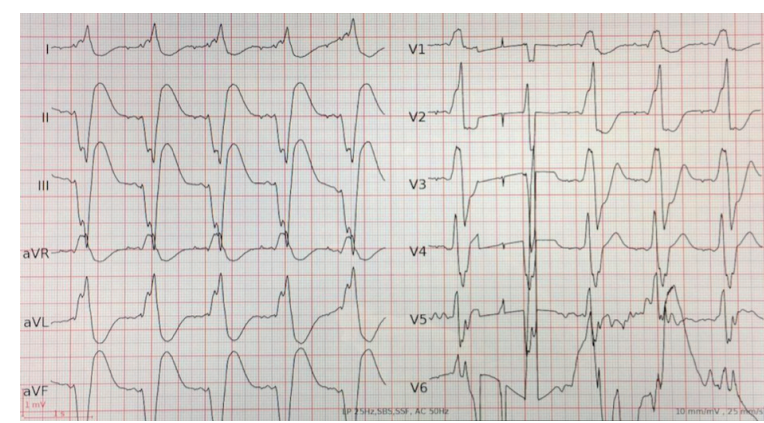

Şekil 3. İndeks vakanın 32,5 yaşındaki elektrokardiyografi görüntüsü

yokimyasal kan parametreleri, serumda serbest tirok$\sin$ (FT4) 25,52 pmol/L (referans değerleri; 11,5-22,7) olarak arttığı, tiroid stimülan hormon (TSH) 3.92 uIU/mlL (referans değerleri; 0,25-4,55) olarak normal aralıkta olduğu belirlendi. 1 hafta sonra tekrarlanan ölçümlerde serbest tiroksin (FT4) 29,04 pmol/L (referans değerleri; 11,5-22,7) olarak arttığı, tiroid stimülan hormon (TSH) $1.61 \mathrm{uIU} / \mathrm{mlL}$ (referans değerleri; 0,25-4,55), serbest triiodotironin (FT3) 3.91 $\mathrm{pmol} / \mathrm{L}$ (referans değerleri; 3.5-6.5) olarak normal aralıkta olduğu belirlendi. Hasta, 34 yaşında ciddi kalp yetmezliği ve pompa yetersizliği sebebiyle eksitus olduğunda, kardiyak amiloidozu histopatolojik olarak incelenemedi. Hastanın klinik takip aşamaları Tablo 1'de özetlenmektedir.

İncelenen Illumina TruSight kardiyomiyopati gen paneli bölgeleri \%98 oranında dizilenmiş olup indeks vakada 97 varyant tespit edildi ve filtrelemeler ardından aminoasit değişimine sebep olan ve klinik önemi belirsiz TTR geninde $\mathrm{H} 90 \mathrm{~N}$ varyant 1 heterozigot olarak tespit edildi. TTR genindeki $\mathrm{H} 90 \mathrm{~N}$ varyantı için yapılan aile segragasyonu incelemesinde, klinik bulguları olmayan babanın taşıyıcı olduğu tespit edildi. Şekil 4'de Sanger dizileme sonucu gösterilmektedir.

\section{H90N ve Non-amiloidojenik Varyantların Biyoinformatik Değerlendirmesi}

Literatürde TTR geninde non-amiloidojenik olarak gruplandırılmış 12 farklı yanlış anlamlı (missens) varyant mevcuttur. Amiloidojenik olarak sinıfland1rılan H90D ve A109S varyantları ile aynı poziyondaki non-amiloidojenik varyantlar birlikte biyoinformatik analizlerle incelendi. Toplam 14 adet varyant, Şekil 5'de gösterildiği gibi açık erişimli veribankaları 
Tablo 1. İndeks vakanın klinik bulguları

\begin{tabular}{|c|c|c|}
\hline Takip Dönemleri & Bulgular & $\begin{array}{c}\text { Klinik } \\
\text { Operasyonlar }\end{array}$ \\
\hline 2001 & $\begin{array}{c}\text { HCM (hipertrofik } \\
\text { kardiomiyopati) } \\
\text { tanısı }\end{array}$ & \\
\hline 2006 & $\begin{array}{l}\text { Tam atriyoventrikü- } \\
\text { ler blok }\end{array}$ & $\begin{array}{l}\text { DDD Kalp Pili } \\
\text { implantasyonu }\end{array}$ \\
\hline 2013 & $\begin{array}{l}\text { Ekokardiyografi: } \\
\text { EF: \%60, lv ve rv } \\
\text { konsantrik hipert- } \\
\text { rofi, ivs:3.3, pdk: } \\
2.4, \text { my: } 1 . \text { seviye }\end{array}$ & $\begin{array}{l}\text { Lead extraction } \\
\text { ICD değişimi }\end{array}$ \\
\hline 2014 & $\begin{array}{l}\text { EF: \%40, biventri- } \\
\text { küler hipertrofi }\end{array}$ & \\
\hline $\begin{array}{l}2016 \text { Mart ve } \\
\text { Nisan }\end{array}$ & $\begin{array}{c}\text { EF: \%35, ivs: } 3.1, \\
\text { pw: } 2.1\end{array}$ & $\begin{array}{l}\text { CRT yükseltme, } \\
\text { lead revizyonu }\end{array}$ \\
\hline 2016 Temmuz & atriyal flutter & $\begin{array}{c}\text { Intrakardiyak } \\
\text { kardiyoversiyon }\end{array}$ \\
\hline 2016 Kasım & Uygun ICD şoku & $\begin{array}{c}\text { VT kardiyover- } \\
\text { siyon }\end{array}$ \\
\hline 2017 & $\begin{array}{l}\text { EF: \%20, biventri- } \\
\text { küler hipertrofi ve } \\
\text { lv dilatasyon }\end{array}$ & $\begin{array}{l}\text { Rektal Biyopsi } \\
\text { (Kongo kırmı- } \\
\text { zisı boyamas1): } \\
\text { amiloid birikimi } \\
\text { negatif }\end{array}$ \\
\hline 2019 & $\begin{array}{l}\text { İleri kalp yetmezli- } \\
\text { gi ile eksitus }\end{array}$ & \\
\hline
\end{tabular}

EF: Ejeksiyon fraksiyonu, lv: sol ventrikül, rv: sağ ventrikül, ivs: intraventriküler septum, pdk: diyastolik posterior duvar kalınlığı, my: mitral yetersizliği, ICD: implante edilebilir kardiyoverter defibrilatör

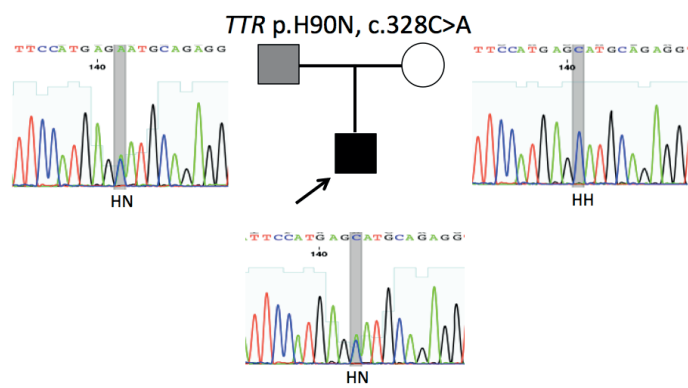

Şekil 4. TTR p.H90N (c.328C >A) varyantının aile segregasyonu. Ok, indeks vakayı, gri kare, asemptomatik taşıyıcı babayı göstermektedir

ve biyoinformatik araçlar kullanılarak in siliko analizlerle karşılaştırıldı. Şekil 5'de, sinyal peptid (20 aminositlik) çıkartıldıktan sonra oluşan matür polipeptiddeki pozisyonları, referans transkriptteki nükleotid pozisyonları dikkate alınarak, HGMD'de ve dbSNP veribankalarında daha önce tanımlanmış olanların kodları belirtildi. Ayrıca her bir varyantın, ACMG sinıflamasına göre belirlenen klinik önemle- ri, popülasyonlardaki sıklıkları ile in siliko analizlere göre verilen varsayım sonuçları kıyaslandı. Buna göre, $\mathrm{H} 90 \mathrm{~N}$ varyantı dahil 10 varyantın popülasyon gruplarında 1/1000'den daha nadir bulunduğu belirlendi. In siliko analizlerde, $\mathrm{H} 90 \mathrm{~N}$ varyant, FATHMM, SIFT, PROVEAN, PrimateAl ve GERP araçlarında zararlı veya riskli skor olarak öngörülürken DANN ve $\mathrm{Mu}$ tationTaster araçlarında ise polimorfik olarak öngörüldüğü belirlendi. Diğer varyanların analiz sonuçları, Şekil 5'de karşılaştırılmaktadır.

\section{TARTIŞMA}

Bu çalışmada, yaklaşık 18 yıl takip edilen biventriküler konsantrik hipertrofili erkek hastada TTR geninde saptanan $\mathrm{H} 90 \mathrm{~N}$ varyantı ile birlikte diğer non-amiloidojenik varyantlar, biyoinformatik analizler ile karşılaştırılarak klinik önemleri ve hastalık patogenezindeki olası etkileri araştırıldı.

Kardiyak amiloidozda EKG'de düşük voltaj ve ekokardiyografide artmış duvar kalınlığının görülmesi tipik bulgulardır (6). Vakamızda AV blok nedeni ile kalıcı pil ritmi olduğundan EKG'de düşük voltaj değerlendirilemezken amiloidoz ile uyumlu biventriküler duvar kalınlığı izlendi. Ayrıca kardiyak amiloidozda atrioventriküler blok, hastaların \%22'sinde görülebilmektedir (6). Vakamızada AV tam blok nedeni ile 21 yaşında kalıcı kalp pili implantasyonu yapıld. Kardiyak amiloidozda, global sol ventrikül sistolik fonksiyonları ve ejeksiyon fraksiyonu hastalığın ileri safhalarına kadar korunmakta, sistolik fonksiyonda zamanla ilerleyici bozulma izlenmektedir (6). Benzer olarak, vakamızda da yıllar içerisinde sol ventrikül sistolik fonksiyonunda ilerleyici azalma meydana gelmiştir.

H90N varyantının klinik önemi belirsiz olup non-amiloidojenik olarak tanımlanmaktadır $(7,10)$. Bu varyantla ilgili ilk araştırma, 1989 yılında, ailesel amiloidotik polinöropatisi olan bir vakada (İtalyan kökenli Amerikalı, 39 yaş, kadın, 34 yaş başlangıçlı sensör nöropati, tek gözde vitröz opasite, muhtemelen nöropati sebebi ile eksitus olmuş anne, amca ve teyzesinde periferal nöropati, kardiyomiyopati ve vitröz opasite, hastanın vitröz sıvısında amiloid fibrilleri immunohistokimya ile gösterilen) TTR geninin 


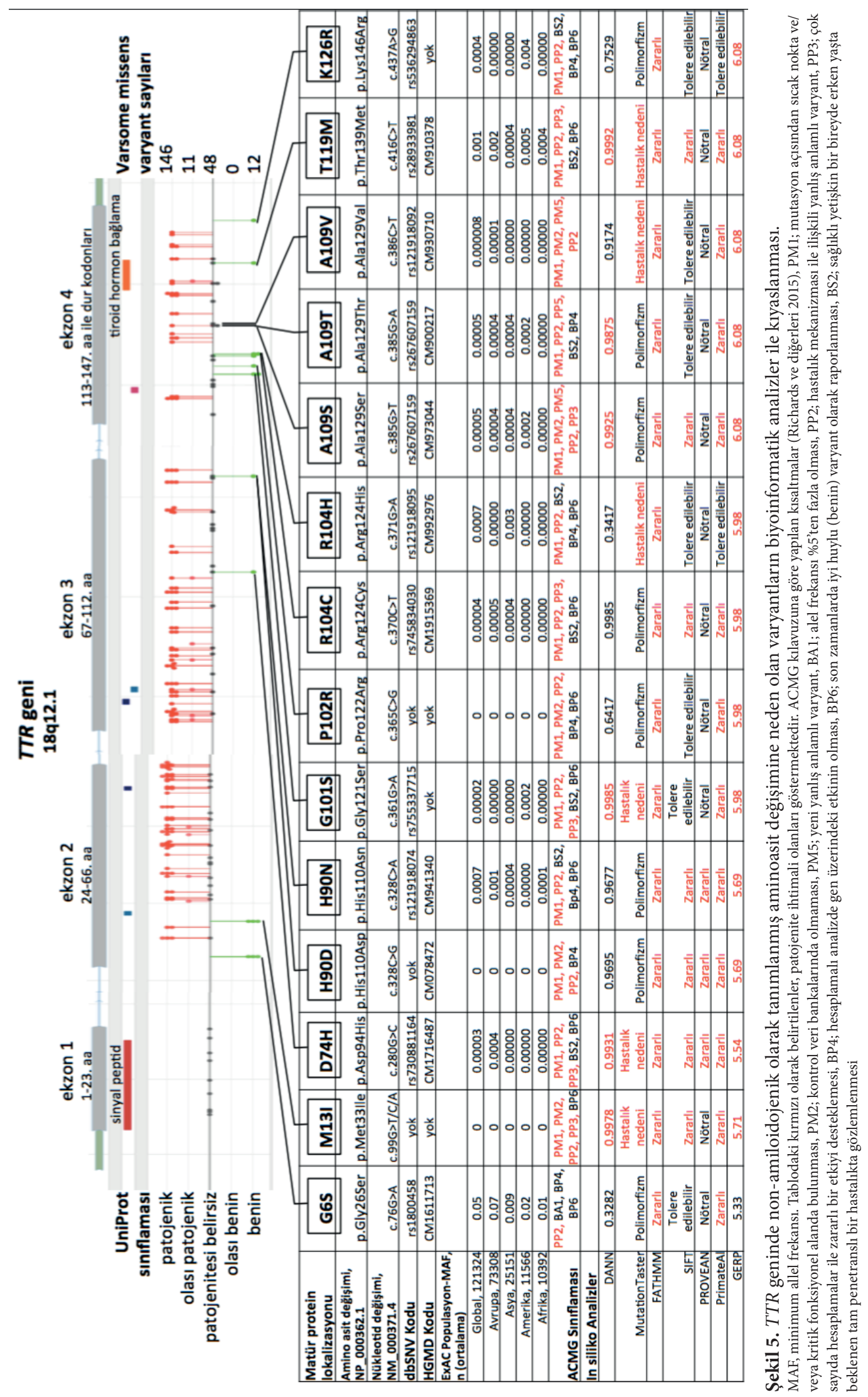


3. ekzonunda SphI restriksiyon enzim kesim bölgesinde 3 amino asitin değişimine sebep olabilecek (glu89, his90 veya ala91) bir değişim belirlenmiş, isoelektrik fokuslama (HIEF, "Hyprid isoelectric focusing in immobilized pH gradient”) tekniği ile plazma transtiretin PI değerleri ile daha asidik bir aminoasite değişim olabileceği (ki 90 ve 91 kodonlardaki aminoasitler) öne sürülmüş ancak nükleotid değişimi o dönemdeki moleküler teknikler ile belirlenememiştir (13). Araştırmacılar, 1991 y1lında bu vakadaki varyantı tanımlamak için 3. ekzonun PCR fragmentini farklı restiksiyon enzimleri kullanarak incelemişler ancak yine H90N değişimini kanıtlayamamışlardır (14). 1994 yılında aynı indeks vakada, abdominal yağ aspiratında amiloid fibrilleri gösterilmiş, kardiyomiyopatisinin ilerlediği ve 42 yaşında ortotopik karaciğer transplantasyonunun yapıldığı bildirilmiştir. Ayrıca, TTR genin dört ekzonik bölgesi dizilenerek ekzon 3'deki c.328C > A değişimi ile oluşan $\mathrm{H} 90 \mathrm{~N}$ varyantı tespit edilmiş aynı zamanda ekzon 2'de E42G (Glu42Gly) substitusyonuna sebep ikinci bir varyant belirlenmiştir (15). E42G varyant1, daha önce alt ekstremite nöropatisi ve kronik diare bulguları olan Japon bir ailede gösterilmiştir (16). Bu İtalyan ailenin aile ağacı sorgulamasında $\mathrm{H} 90 \mathrm{~N}$ ve $\mathrm{E} 42 \mathrm{G}$ varyantlarının birlikte indeks vakanın ölen annesinden segrege olduğu, indeks vakanın 6 kardeşinden 2'sinde (biri 36 yaşında iken abdominal yağ dokusunda amiloid tespit edilmiş ve sensör nöropatisi meydana gelince 37 yaşında karaciğer transplantasyonu olmuş erkek kardeş ile dört yıl önceki klinik değerlendirmesinde 37 yaşında iken asemptomatik olan erkek kardeş) ve ayrıca semptomatik 3 kuzeninde de bu varyantların cis konfigürasyon ile birlikte bulunduğu belirlenmiştir (15). Sonuç olarak, H90N varyantı ilk kez bu çalışmada tespit edilmiş olsa da çalışmamızdaki vakadan farklı olarak nöropati ile seyri ve amiloid birikimi ile ilişkinin amiloidojenik olan ikinci varyantın birleşik heterozigositesinden kaynaklanmaktadır.

1991 yılında başka bir çalışmada (17), 1200 kişilik Portekiz populasyonunda ki bunların 500'ü V30M (Val30Met) varyantlı FAP hastaları ile asemptomatik aile üyeleri ve FAP’ın sık görüldüğü bir bölgede (Po- voa de Varzim) yaşayan 700 kişilik random populasyonda HIEF tekniği (18) ile plazmada TTR protein varyantları taranmış ve bunlar içerisinden asidik TTR varyantı olan bir aile belirlenmiştir. Bu ailedeki FAP'lı indeks vaka, amiloidojenik olan V30M varyantı için heterozigot iken aseptomatik 31 yaşındaki oğlunun V30M ve H90N varyantları için bileşik heterozigot olduğu (plazmada normal TTR monomeri olmayıp H90N varyantı annesinden segrege olmuştur, trans konfigürasyonda) ve 28 yaşındaki kızının ise sadece H90N varyantı için taşıyıcı olduğu belirlenmiştir (17). Ayrıca bu çalışmaya deneysel karşılaştırma amacı ile, Altland ve arkadaşlarının 1987 yılındaki çalışmasında (19) aynı teknikle 4000 kişi taranarak non-patojenik asidik TTR varyantını taşıdı̆̆ı saptanmış, akrabalıkları olmayan 2 Alman birey (klinik bilgileri mevcut değil) dahil edilmiştir (17). Ek olarak, 700 kişilik Portekiz popülasyonunda H90N varyantı 3 kişide (biri homozigot olarak) daha tespit edilmiş ve bu bireylerin (6-58 yaş) sağlıklı ve FAP bulgularına sahip olmadığı belirtilerek H90N varyantının hastalıkla ilişkili olmadığı ileri sürülmüştür (17). 1992 yılında Alves ve arkadaşları tarafından, İtalyan indeks vaka ve asemptomatik kardeşinde (13) ve Portekizli 3 bireyde (17) HIEF tekniği ile elde edilen asidik TTR varyant sonuçları, TTR ekzonları dizilenerek H90N substitusyonuna neden olan c.328C $>$ A nükleotid değişimini ve genotiplerini konfirme edilmiştir (20). $\mathrm{Bu}$ asemptomatik ve sağlıklı olarak değerlendirilmiş H90N varyant taşıyıcılarının ileri yaşlardaki nörolojik ve kardiyak takipleri ile ilgili literatürde herhangi bir bilgiye rastlanmamıştır. Dolayısıyla sağlıklı olarak incelenen Portekiz popülasyonu FAP'ın sık rastlan-

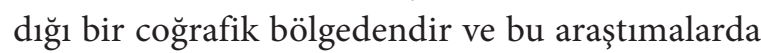
H90N varyant taşıyıcılığının kardiyak amiloidoz açısindan değerlendirilmemiştir. Bu sebeple, H90N gibi non-amiloidojenik olarak sinıflandırılan, nadir ve patojenite ihtimali bulunan varyant taşıyıcılarının kardiyolojik takipleri önem taşıyabilir.

1993 yılındaki bir çalışmada, Kuzey Portekiz’de V30M varyantını taşıyan FAP ailelerinde hasta ve etkilenmemiş aile bireylerinin serum örnekleri ( $\mathrm{n}=100)$ HIEF yöntemi ve TTR ekzonları PCR-PFLP yöntemleri ile incelenmiştir (21). Bu ailede, 37 yaşın- 
daki V30M taşıyıcısı FAP'lı hastanın (eksitus) 55 yaşındaki ablasının T119M (diğer bir non-amiloidojenik varyant) heterozigot taşıyıcı, eşinin $\mathrm{H} 90 \mathrm{~N}$ heterozigot taşıyıcı olduğu ve bu çiftin 24 yaşındaki oğlunda H90N ve T119M birleşik heterozigotluk tespit edilmiştir. $\mathrm{Bu}$ üç bireyde FAP semptomlarının olmadığ 1 ancak T119M varyantına sahip bireyde T4 hormonunun taşınmasında TTR bağlanmasının arttığı, H90N taşıyıcılığının ise hormon bağlama özelliklerinde veya konsantrasyonlarına etkisinin olmadığı belirlenmiştir (21). Ancak bu çalışmada da, bu aile bireyleri kardiyolojik olarak incelenmemiştir ve izlemleri hakkında bilgi mevcut değildir.

2004 yılındaki başka bir çalışmada ise (22), 5 hastanın incelendiği Hollandalı bir FAP'lı ailede, indeks vaka, annesi (72 yaşında ciddi amiloidoz ile eksitus olmuş) ve 2 kız kardeşinde G47E (Gly47Glu) patojenik varyantı tespit edilmiş, ek olarak indeks vakanın yeğeni olan 33 yaşındaki karpal tünel sendromu tanısı alıp sonra 43 yaşında şiddetli amiloid kardiyomiyopatisi, sistemik ortostoz ve gastarointestinal mobilite bozukluğu ile duyu polinöropatisi ve böbrek yetmezliği tanısı alan bir kadın hastada, hem G47E varyantı (babası ile ilgili klinik ve genetik bilgi mevcut değildir) hem de H90N (muhtemelen klinik bilgisi mevcut olmayan annesinden kalıtılmış) varyantı saptanmıştır. Bileşik hetrozigot olan bu hastanın kalbinde patolojik olarak ciddi amiloid birikimi tespit edilmiş, kalp ve karaciğer transplantasyonundan 4 ay sonra ani bir şekilde ölmüştür. Çalışmada, H90N varyantının olası etkisi tartışmada belirtilmemiştir (22). H90N varyant1, amiloidojenik G47E varyant1 ile birlikte bu vakada klinik bulguların daha şiddetli oluşmasına sebep olmuş olabilir.

2009 yılındaki araştırmada, tekrarlayan serebral kanamaları olan, kardiyak ve periferal nöropati bulguları bulunmayan, abdominal yağ biyopsisinde amiloid belirlenememiş 46 yaşında bir erkek hastada ve asemptomatik iki kız kardeşinde ( 40 ve 46 yaş) H90N varyantı tespit edilmiştir. Kız kardeşlerin serebral görüntülemesinde periventriküler beyaz cevherde çok az spesifik olmayan yüksek sinyal yoğunluğu lezyonları görülmüş ancak bulgular amiloidozu desteklememiştir. Diğer yandan, indeksin babasında serebral hemoraji hikayesi olmasına rağmen bu varyantı taşımadığ ölmüş olan anne hakkında bilgi verilmemiştir (23). $\mathrm{Bu}$ çalışmada, $\mathrm{H} 90 \mathrm{~N}$ varyantının amiloidojenik bir potansiyele sahip olmadığ ileri sürülmüş olsa da vakanın annesi ve kız kardeşlerinde kardiyak amiloidoz durumu değerlendirilmemiştir.

2011 yılında, Rus kardiyomiyopati hastalarında $(\mathrm{n}=270)$ TTR gen varyantları araştırılmış ve 42 yaşında tanı almış H90N varyant taşıyıcısı hastada, majör bulgular olarak progresif kardiyopulmoner yetmezlik, akciğer arter dallarında tekrarlayan tromboemboli, periferik ödem ve asidemi tarif edilmiștir (24). Bu hastada, kardiyak amiloidozun klinik tanısı, sol ventrikülde miyokardiyal kitle indeksinde belirgin bir artış ve elektrokardiyografik dinamik voltajın azalmasıyla ortaya çıkan kardiyovasküler ve solunum sistemlerinin açık tutulumu sırasında hastalığın terminal aşamasında konulmuştur. Hastanın ölümü, aniden sinoatriyal blokaj nedeniyle olmuştur. Otopside, sistemik ve ağırlıklı kardiyopulmoner amiloidoz formunun hafif aterosklerozlu koroner arterlerde olduğunu belirlenmiştir. İmmünohistokimyasal çalışmalarda AL amiloidoz olmadığ İndeks vaka hastalığın klinik bulgularına sahip olmayan annesinde (74 yaş) de H90N varyantı tespit edilmiştir (24). Bu vakanın klinik izlemi ve semptomatik olmadığı için sağlıklı olarak değerlendirilmiş bir ebeveyninden kalıtılması açısından çalışmamızdaki vaka ile benzerdir. Transtiretin (TTR) amiloidozu, otozomal dominant olarak kalıtıldığı ve değişken penetransa sahip olması sebebi ile H90N varyantına sahip vakalardaki klinik heterojenite, başka modifiye edici genetik ve epigenetik faktörlerden kaynaklanıyor olabilir.

2015 yılında, FAP hikayesi olan geniş bir İrlandalı ailede, TTR c.328C > G nükleotid değişimi sonucu ile oluşan H90D varyantı ilk kez tanımlanmıştır (10). 74 yaşındaki polinöropatili kadın indeks vakanın sinir biyopsisinde amiloid depozitleri gösterilmiş, 10 yıl öncesinde karpal tünel sendromu sonrasında alt bacak güçsüzlügü gelişmiş hasta 80 yaşında konjestif kalp yetmezliği ile eksitus olmuştur. Probandın 54 yaşındaki H90D taşıyıcısı kızı, kardiyolojik açıdan da de- 
ğerlendirilmiş ve anormallik saptanmamıştır (10). Bu çalışmada, in siliko olarak H90D ve H90N varyantlarının PyMoL ile üç boyutlu yapıları karşılaştırılmış ve H90D varyantının H90N’ye göre bağları değiștireceği ve tetramer stabilitesini önemli ölçüde bozabileceği öngörülmüştür (10). H90D varyantı, eksitus olan vakada yapılan sinir biyopsisinde amiloid birikimi gösterilebildiği için amiloidojenik varyant olarak sınıflandırılmıştır (10). Ancak literatürde sadece H90N taşıyıcısı Rus vaka (24) otopsisi dışında hiç bir vakada amiloid birikimi gösterilememiştir. Bu çalışmadaki en önemli kısitllık, vakamız hayattayken invaziv bir girişim olan kardiyak biyopsinin yapılmaması ve eksitus sonrası sosyopsikolojik nedenlerle dokularında histopatolojik değerlendirme yapılamamış olmasıdır. İleride benzer otopsi vakalarında, farklı dokularda amiloid birikimleri histopatolojik olarak belirlenebilir. Amiloidoz tanısında, görüntüleme yöntemlerindeki ilerlemelere rağmen doku biopsisi halen altın standart olarak değerlendirilse de (6) vakamızdan alınan rektal biyopside amiloid birikimi gösterilememiş olup birikim olabilecek diğer dokular incelenememiştir.

TTR ile ilişkili amiloidoz yaş, cinsiyet, coğrafi bölgeler, epigenetik değişiklikler ve çevresel faktörlere göre fenotipik varyasyonlarla birçok farklı formda ortaya çıkabilmektedir (6). Sonuç olarak, literatürde H90N varyantının kardiyak amiloidozdaki patojenik etkisi ile ilgili veri eksikliği mevcuttur. Bu çalışmada, özellikle nadir rastlanan ve in siliko analizlerle patojenik olarak tahmin edilen non-amiloidojenik varyantların amiloidoz patogenezinde rol onayabileceği öne sürülmektedir. Ancak bu hipotezi destekleyecek daha fazla deneysel ve takipli klinik araştırmaya ihtiyaç duyulmaktadır.

Teşekkür: PCR primerlerinin temininden Mehveş Poda’ya teşekkür ederiz.

Acknowledgements: Thanks to Mehveş Poda for providing PCR primers.

Etik Komite Onayı: Bu çalışma için etik komite onayı İstanbul Üniversitesi İstanbul Tip Fakültesi Etik Kurulu’ndan alınmıştır.

Ethics Committee Approval: This study was approved by the Ethical Committee of the Istanbul University Istanbul Faculty of Medicine.
Bilgilendirilmiş Onam: Katılımcılardan bilgilendirilmiş onam alınmıştır.

Informed Consent: Written consent was obtained from the participants.

Hakem Değerlendirmesi: Dış bağımsız.

Peer Review: Externally peer-reviewed.

Yazar Katkıları: Çalışma Konsepti/Tasarım E.K.B, G.Ç.; Veri Toplama- E.K.B, E.E., G.K., F.B.; Veri Analizi/Yorumlama- E.K.B, E.E., G.K., F.B.; Yazı Taslağ1E.K.B, F.B.; İçeriğin Eleștirel İncelemesi- F.B.; Son Onay ve Sorumluluk- E.K.B, G.Ç., E.E., G.K., F.B.

Author Contributions: Conception/Design of Study- E.K.B, G.Ç.; Data Acquisition- E.K.B, E.E., G.K., F.B.; Data Analysis/Interpretation- E.K.B, E.E., G.K., F.B.; Drafting Manuscript- E.K.B, F.B.; Critical Revision of Manuscript- F.B.; Final Approval and Accountability- E.K.B, G.Ç., E.E., G.K., F.B.

Çıkar Çatışması: Yazarlar çıkar çatışması beyan etmemişlerdir

Conflict of Interest: Authors declared no conflict of interest.

Finansal Destek: Bu çalışma, İstanbul Üniversitesi Bilimsel Araştırma Projeleri Birimi tarafından desteklenmiştir (Proje No: 42173 ve TDP-2017-22581).

Financial Disclosure: This study was supported by Istanbul University Scientific Research Projects Unit. (Project No: 42173 and TDP-2017-22581).

\section{KAYNAKLAR/REFERENCES}

1. Riek R, Eisenberg DS. The activities of amyloids from a structural perspective. Nature 2016; 539(7628):227-35.

2. Angelini A, Zanco F, Castellani C, Di Francesco A, Barbera MD, Vescovo GM, et al. Cardiac amyloidosis: a review of the literature and a practical approach for the clinicians. Italian Journal of Medicine 2019; 13: 73-90.

3. Guan J, Mishra S, Falk RH, Liao R. Current perspectives on cardiac amyloidosis. Am J Physiol Heart Circ Physiol 2012; 302(3):H544-H552.

4. Ruberg FL, Berk JL. Transthyretin (TTR) cardiac amyloidosis. Circulation 2012; 126(10): 1286-300.

5. Park GY, Jamerlan A, Shim KH, An SSA. Diagnostic and Treatment Approaches Involving 
Transthyretin in Amyloidogenic Diseases. Int J Mol Sci 2019;20(12):2982.

6. Kocabaş GÜ, Kocabaş U, Gültekin N. Kardiyak Amiloidoz; Patofizyoloji, Teşhis ve Tedavi. Gültekin $\mathrm{N}$, editör. İnfiltratif Kardiyomiyopatiler, Lizozomal Depo Hastalıkları, Mitokondriyal ve Genetik Mutasyonlara Bağlı Kardiyomiyopatiler. Ankara: Türkiye Klinikleri 2018; p.11-22.

7. Saraiva MJ. Transthyretin mutations in hyperthyroxinemia and amyloid diseases. Hum Mutat 2001;17(6):493-503.

8. Date Y, Nakazato M, Kangawa K, Shirieda K, Fujimoto T, Matsukura S. Detection of three transthyretin gene mutations in familial amyloidotic polyneuropathy by analysis of DNA extracted from formalin-fixed and paraffin-embedded tissues. J Neurol Sci 1997;150(2):143-8.

9. Refetoff S, Marinov VS, Tunca H, Byrne MM, Sunthornthepvarakul T, Weiss RE. A new family with hyperthyroxinemia caused by transthyretin Val109 misdiagnosed as thyrotoxicosis and resistance to thyroid hormone--a clinical research center study. J Clin Endocrinol Metab 1996; 81(9):3335-40.

10. Jimenez-Zepeda VH, Bahlis NJ, Gilbertson J, Rendell N, Porcari R, Lachmann HJ, et al. A novel transthyretin variant p.H110D (H90D) as a cause of familial amyloid polyneuropathy in a large Irish kindred. Amyloid 2015;22(1):26-30.

11.Durmuş-Tekçe H, Matur Z, Mert Atmaca M, Poda M, Çakar A, Hıdır Ulaş Ü, et al. Genotypic and phenotypic presentation of transthyretinrelated familial amyloid polyneuropathy (TTRFAP) in Turkey. Neuromuscul Disord 2016; 26(7):441-6.

12. Richards S, Aziz N, Bale S, Bick D, Das S, Gastier-Foster J, et al; ACMG Laboratory Quality Assurance Committee. Standards and guidelines for the interpretation of sequence variants: a joint consensus recommendation of the American College of Medical Genetics and Genomics and the Association for Molecular Pathology. Genet Med 2015; 17(5):405-24.
13. Skare JC, Saraiva MJ, Alves IL, Skare IB, Milunsky A, Cohen AS, et al. A new mutation causing familial amyloidotic polyneuropathy. Biochem Biophys Res Commun 1989;164(3):1240-6.

14. Skare JC, Milunsky JM, Milunsky A, Skare IB, Cohen AS, Skinner M. A new transthyretin variant from a patient with familial amyloidotic polyneuropathy has asparagine substituted for histidine at position 90. Clin Genet 1991;39(1):6-12.

15. Skare J, Jones LA, Myles N, Kane K, Milunsky A, Cohen A, et al. Two transthyretin mutations (glu42gly, his90asn) in an Italian family with amyloidosis. Clin Genet 1994;45(6):281-4.

16. Ueno S, Uemichi T, Takahashi N, Soga F, Yorifuji S, Tarui S. Two novel variants of transthyretin identified in Japanese cases with familial amyloidotic polyneuropathy: transthyretin (Glu42 to Gly) and transthyretin (Ser50 to Arg). Biochem Biophys Res Commun 1990; 169(3):1117-21.

17. Saraiva MJ, Almeida MR, Alves IL, Moreira P, Gawinowicz M, Costa PP, Rauh S, Banhzoff A, Altland K. Molecular analyses of an acidic transthyretin Asn 90 variant. Am J Hum Genet 1991;48(5):1004-8.

18. Altland K, Banzhoff A. Separation by hybridisoelectric focusing of normal human plasma transthyretin (prealbumin) and a variant with a methionine for valine substitution associated with familial amyloidotic polyneuropathy. Electrophoresis 1986; 7(11):529-33.

19. Altland K, Becher P, Banzhoff A. Paraffin oil protected high resolution hybridisoelectric focusing for the demonstration of substitutions of neutral amino acids in denatured proteins: the case off our human transthyretin (prealbumin) variants associated with familial amyloidotic polyneuropathy. Electrophoresis 1987;8(6): 293-7.

20. Alves IL, Almeida MR, Skare J, Skinner M, Kurose K, Sakaki Y, Costa PP, Saraiva MJ. Amyloidogenic and non-amyloidogenic transthyretin Asn 90 variants. Clin Genet 1992;42(1):27-30. 
21. Alves IL, Divino CM, Schussler GC, Altland K, Almeida MR, Palha JA, et al. Thyroxine binding in a TTR Met 119 kindred. J Clin Endocrinol Metab 1993; 77(2):484-8.

22. Haagsma EB, Hawkins PN, Benson MD, Lachmann HJ, Bybee A, Hazenberg BP. Familial amyloidotic polyneuropathy with severe renal involvement in association with transthyretin Gly47Glu in Dutch, British and AmericanFinnish families. Amyloid 2004;11(1):44-9.

23. Bersano A, Del Bo R, Ballabio E, Cinnante C, Lanfranconi S, Comi GP, et al. Transthyretin
Asn90 variant: amyloidogenic or nonamyloidogenic role. J Neurol Sci. 2009; 284(12):113-5.

24. Solov'ev KV, Grudinina NA, Semernin EN, Morozova IV, Smirnova SA, Poliakov DS, Aleŭnikova TD, Shliakhto EV, Gudkova AY, Shavlovskiir MM. Transthyretin gene V30M, $\mathrm{H} 90 \mathrm{~N}$, and del9 mutations in cardiomyopathy patients from St. Petersburg. Genetika. 2011;47(4):543-9. 